\title{
Population structure of the loggerhead turtle Caretta caretta, a large marine carnivore that exhibits alternative foraging behaviors
}

\author{
Kunihiro K. Watanabe ${ }^{1,9}$, Hideo Hatase ${ }^{1, *}$, Masato Kinoshita $^{2}$, Kazuyoshi Omuta $^{3}$, \\ Takeharu Bando ${ }^{4}$, Naoki Kamezaki ${ }^{5}$, Katsufumi Sato ${ }^{6}$, Yoshimasa Matsuzawa ${ }^{5}$, \\ Kiyoshi Goto ${ }^{7}$, Yoshito Nakashima ${ }^{8}$, Hiroshi Takeshita ${ }^{8}$, Jun Aoyama ${ }^{1}$, \\ Katsumi Tsukamoto ${ }^{1}$
}

\footnotetext{
${ }^{1}$ Atmosphere and Ocean Research Institute, The University of Tokyo, 5-1-5 Kashiwanoha, Kashiwa, Chiba 277-8564, Japan

${ }^{2}$ Graduate School of Agriculture, Kyoto University, Sakyo, Kyoto 606-8502, Japan

${ }^{3}$ Yakushima Sea Turtle Research Group, 489-8 Nagata, Yakushima, Kagoshima 891-4201, Japan

${ }^{4}$ Institute of Cetacean Research, 4-5 Toyomi, Chuo, Tokyo 104-0055, Japan

${ }^{5}$ Sea Turtle Association of Japan, 5-17-18-302 Nagao-motomachi, Hirakata, Osaka 573-0163, Japan

${ }^{6}$ International Coastal Research Center, Atmosphere and Ocean Research Institute, The University of Tokyo, Otsuchi, Iwate 028-1102, Japan

${ }^{7}$ Minabe Sea Turtle Research Group, 278 Higashiyoshida, Minabe, Wakayama 645-0001, Japan

${ }^{8}$ Miyazaki Wildlife Animal Research Group, 9779-8 Shimanouchi, Miyazaki 880-0121, Japan
}

${ }^{9}$ Present address: National Institute for Land and Infrastructure Management, 1 Asahi, Tsukuba, Ibaraki 305-0804, Japan

\begin{abstract}
Knowledge of detailed population genetic structure is crucial to conserve and manage endangered species effectively. Size-related variation in feeding-habitat use (neritic vs. oceanic) by adult loggerhead turtles Caretta caretta has been reported within several populations, and sympatric population subdivision was suspected. In the present study, genetic differences between the 2 feeding-habitat groups within 2 Japanese nesting sites were assessed, using 5 microsatellite loci and mitochondrial (mt) DNA sequences. There were no genotypic or haplotype differences between the feeding-habitat groups, which were defined by egg-yolk stable isotope ratios and body size, at both nesting sites, suggesting that both neritic and oceanic individuals belong to the same genetic population. Differences in feeding-habitat use are unlikely to be a limiting factor for gene flow between feeding-habitat groups and were thought to be the result of phenotypic plasticity rather than population subdivision. Gene flow among 5 nesting sites was assessed by pooling these feeding-habitat groups at each nesting site. Significant genetic structure by female natal homing was observed at the mtDNA level. However, no significant structure was found at the microsatellite DNA level, suggesting male-mediated gene flow caused by migration through courtship areas. Although nesting beaches are connected by male-mediated gene flow, which might have evolved as a mechanism to avoid genetic fragmentation by natal homing, extirpated beaches would not be easily recolonized from other nesting populations due to female philopatry. Therefore, conservation of individual nesting beaches is still needed to maintain the overall genetic diversity of Japanese loggerheads.
\end{abstract}

KEY WORDS: Alternative life histories · Microsatellite DNA · Mitochondrial DNA · Phenotypic plasticity $\cdot$ Reptile $\cdot$ Caretta caretta

Resale or republication not permitted without written consent of the publisher

\section{INTRODUCTION}

Information on population genetic structure is fundamental for recognizing management units of endangered species (Moritz 1994). Because population genetic structure depends on both the resolution and the inheritance modes of genetic markers, it should be analyzed through the combined use of multiple mark- 
ers. Sequences of maternally inherited mitochondrial (mt) DNA and microsatellites of biparentally inherited nuclear DNA are the markers commonly used in recent wildlife population genetics (Frankham et al. 2002). In principle, due to their faster rate of evolution, the resolution of microsatellites is greater than that of mtDNA sequences. Nevertheless, in some cases, population differentiation inferred from mtDNA sequences is stronger than that from microsatellites (e.g. FitzSimmons et al. 1997b, Bowen et al. 2005, Carreras et al. 2007, Chen et al. 2008, Lukoschek et al. 2008, Okello et al. 2008, Caparroz et al. 2009, Hefti-Gautschi et al. 2009, Portnoy et al. 2010), and this has been attributed to sex differences in natal philopatry and dispersal.

Individuals sampled at a location are usually treated as a single population in wildlife population genetics (Frankham et al. 2002). However, if they show intrapopulation polymorphisms in life history, sympatric population subdivision should be assessed before examining overall population structure. Intra-population polymorphisms in life history have been observed in several types of animals such as insects (Harrison 1980), fishes (Tsukamoto et al. 1998), amphibians (Wilbur \& Collins 1973) and birds (Lundberg 1988). For example, some salmonid fishes have mature individuals of 2 types - sea/lake run and river resident types (Thorpe 1986, Olsson et al. 2006) - and the river resident type is smaller than the sea/lake run type. Whether there are genetic partitions between alternative phenotypes varies among species (e.g. Berthold 1991, Voss 1995, Jones et al. 1997, Braendle et al. 2005, Hoelzel et al. 2007). The occurrence and maintenance of alternative life histories have become important issues in evolutionary ecology (Gross 1996).

Sea turtles may be a good subject for addressing the aforementioned issues related to both conservation/ population genetics and evolutionary ecology. In sea turtles, intra-population polymorphisms in life history were first reported as variation in feeding-habitat use by adult female loggerhead turtles Caretta caretta nesting in Japan (Hatase et al. 2002d, 2007). Loggerhead turtles are generally carnivorous throughout their lives (Dodd 1988). Using stable isotope analysis and satellite telemetry, these studies revealed that, during the non-nesting season, large females foraged mainly on benthic items in neritic waters where water depths are $<200 \mathrm{~m}$, while small females, like the juveniles, foraged mainly on planktonic items in oceanic waters where depths are $>200 \mathrm{~m}$. Because female sea turtles grow little after reaching sexual maturity (Hatase et al. 2004), this phenomenon does not mean that adult females shift habitats with aging. Similar foraging dichotomies have increasingly been reported in loggerheads nesting at Cape Verde (Hawkes et al. 2006) and Florida, USA (Reich et al. 2010), and in green turtles Chelonia mydas nesting at Ogasawara Islands, Japan (Hatase et al. 2006), as well as at the Galápagos Islands, Ecuador (Seminoff et al. 2008). Male loggerheads were also thought to show this type of foraging dichotomy (Hatase et al. 2002c). These findings suggest that intra-population polymorphisms in life history might be common in sea turtles (McClellan \& Read 2007, Caut et al. 2008, Mansfield et al. 2009, McClellan et al. 2010, Zbinden et al. 2011).

Alternative life histories sometimes have a genetic basis coupled with assortative mating (e.g. Maekawa et al. 1994, Bearhop et al. 2005, Ólafsdóttir et al. 2006). Assortative mating may result from morphological mate choice and/or temporal reproductive isolation. In the case of adult loggerheads, because oceanic and neritic foragers are different in body size, they might use this character for mate choice. The timing of arrival to courtship areas, which are generally near nesting beaches (Limpus 1993), might also differ between the 2 feeding-habitat groups, because distances to the courtship areas are different between feeding habitats (Hatase et al. 2002d, 2007). These phenotypic differences might contribute to assortative mating between oceanic and neritic foragers, thus making population subdivision possible.

Although loggerhead turtles are circumglobally distributed in tropical and temperate waters (Dodd 1988), Japan is the only country that hosts nesting beaches for this species within the North Pacific. A substantial decline in the number of nests has been reported among Japanese populations during the last half of the 20th century (Sato et al. 1997, Hatase et al. 2002c, Kamezaki et al. 2003), and actions for conservation are urgently needed. In the present study, we first assessed the relationship between feeding-habitat use, which was reflected in egg-yolk stable isotope ratios and body sizes, and genetic features within Japanese loggerhead turtle nesting beaches, using both mtDNA sequences and 5 microsatellite loci. Second, overall population structure among nesting beaches was examined with the same markers. Based on the results of these analyses, we discuss sex-biased gene flow and conservation of Japanese loggerheads.

\section{MATERIALS AND METHODS}

Sample collection and DNA extraction. From May to August 1994 to 2004, a total of 284 nesting females of the loggerhead turtle Caretta caretta were sampled from 5 nesting sites in southern Japan (Fig. 1, Table 1): Minabe

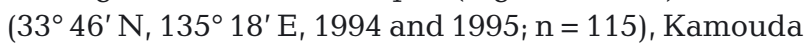
$\left(33^{\circ} 15^{\prime} \mathrm{N}, 134^{\circ} 45^{\prime} \mathrm{E}, 2002\right.$ to $\left.2004 ; \mathrm{n}=10\right)$, Miyazaki $\left(31^{\circ} 47^{\prime}\right.$ to $32^{\circ} 08^{\prime} \mathrm{N}, 131^{\circ} 28^{\prime}$ to $131^{\circ} 32^{\prime} \mathrm{E}, 1995$ and $1999_{\text {; }}$ $\mathrm{n}=46)$, Yakushima (30²4' N, 130 26' E, 1995 and 1999; 
$\mathrm{n}=91$ ), and Fukiagehama $\left(31^{\circ} 30^{\prime} \mathrm{N}, 130^{\circ} 18^{\prime} \mathrm{E}, 1997\right.$ and $1999 ; n=22)$. Nesting females were identified by tagging, and their straight carapace lengths were measured with calipers during nightly patrols (Kamezaki et al. 1997, Sato et al. 1997). Female loggerheads lay several clutches of eggs (ca. 110 eggs clutch $^{-1}$ ) on specific sandy beaches every ca. 2 wk during a nesting season and remigrate there with high fidelity from distant feeding grounds every few years (Dodd 1988). In fact, there are no published records on the exchange of tagged females among the above 5 sampled sites, despite the large number (>2000) of tagged females (Kamezaki et al. 1997). Small pieces of muscle tissue, which were secondarily recovered while punching front flippers of nesting females for attachment of plastic tags, were collected for both microsatellite and mtDNA analyses. In addition, blood samples of 10 hatchlings derived from 10 individual nesting females ( 1 hatchling female ${ }^{-1}$ ) were used to determine mtDNA haplotypes of loggerheads nesting at Kamouda; these were not used in the microsatellite analysis. These hatchlings were collected when they emerged from their nests, which had been marked during the nesting season and enclosed by nets just before the emergence (ca. $60 \mathrm{~d}$ after the oviposition). The eggs from 48 individual loggerhead turtles (1 egg female ${ }^{-1}$ ) were collected at Yakushima for stable isotope analysis (Hatase et al. 2002d).

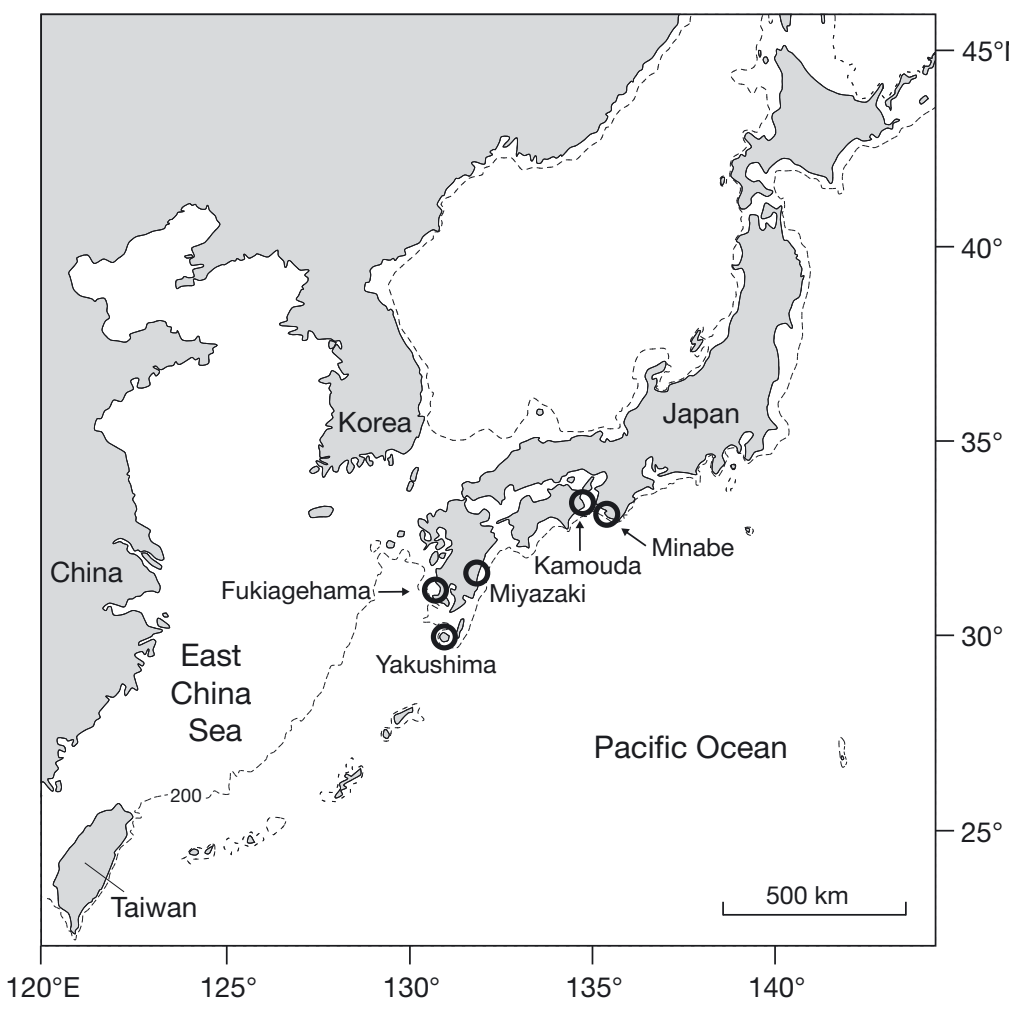

Fig. 1. Caretta caretta. Locations of the 5 nesting sites sampled for loggerhead turtles in southern Japan. Contour line: $200 \mathrm{~m}$ depth
Muscle tissue samples were preserved in a high concentration urea-containing buffer (TNES-Urea: 6 or $8 \mathrm{M}$ urea; $10 \mathrm{mM}$ Tris- $\mathrm{HCl}, \mathrm{pH} 7.5 ; 125 \mathrm{mM} \mathrm{NaCl}_{\text {; }}$

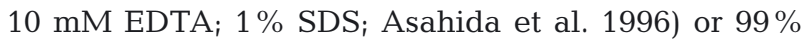
ethanol at room temperature, while blood samples were preserved in a TNES buffer $(100 \mathrm{mM}$ Tris- $\mathrm{HCl}$, pH 8.0; $10 \mathrm{mM} \mathrm{NaCl} ; 100$ mM EDTA; $1 \%$ SDS; Bass et al. 1996) at room temperature. Total DNA was extracted from the samples using a standard phenol/ chloroform (1:1) treatment or DNeasy Tissue Kit (QIAGEN) and then suspended in TE buffer (10 mM Tris$\mathrm{HCl}$, pH 8.0; 1 mM EDTA).

PCR amplification and genotype/haplotype determination. Five microsatellite markers-Cc7, Cc117, Cc141, Cm84, and Ei8 (FitzSimmons et al. 1995, 1999, FitzSimmons 1998) - were used for genotyping. Forward primers were labeled with fluorochrome. Polymerase chain reaction (PCR) amplification was carried out in the Model 9700 thermal cycler (Applied Biosystems) with a $15 \mu \mathrm{l}$ reaction volume containing $100 \mathrm{ng}$ of template DNA, $1 \times$ PCR buffer (TaKaRa), $0.5 \mu \mathrm{M}$ of each primer, $0.2 \mathrm{mM}$ of each $\mathrm{dNTP}$, and $0.4 \mathrm{U}$ ExTaq DNA polymerase (TaKaRa). The PCR amplification condition consisted of initial denaturation at $94^{\circ} \mathrm{C}$ for 5 min, followed by 30 cycles consisting of $30 \mathrm{~s}$ at $94^{\circ} \mathrm{C}$, $1 \mathrm{~min}$ at 55 or $59^{\circ} \mathrm{C}$ (optimal annealing temperature for each primer pair), $30 \mathrm{~s}$ at $72^{\circ} \mathrm{C}$, and a final extraction for $7 \mathrm{~min}$ at $72^{\circ} \mathrm{C}$. Allele sizes were resolved on an ABI 3130xl genetic analyzer (Applied Biosystems). Individual genotypes were assigned using GeneMapper software Ver. 3.5 (Applied Biosystems).

Details of mtDNA analysis are described in Hatase et al. (2002b). A portion (350 base pairs [bp]) of the mtDNA control region was analyzed by direct sequencing of 111 samples collected in the first year at 4 nesting sites (Minabe, Miyazaki, Yakushima, and Fukiagehama), and 7 polymorphic sites were detected as described by Bowen et al. (1995). These polymorphisms resolved 3 haplotypes (A, B, and C: Bowen et al. 1995), which differed by 4 or 5 nucleotide substitutions. Haplotype A is the most dominant in the South Pacific and is designated CCP1 there (Boyle et al. 2009). PCR restriction fragment length polymorphism (RFLP) analysis was alternatively used for 148 samples collected in the second year at the 4 nesting sites to assign the 3 haplotypes. Because the sequenced length for checking polymorphism by Bowen et al. (1995) and Hatase et al. (2002b) was short (350 bp), a longer fragment of $650 \mathrm{bp}$ was sequenced for a preliminary set of 20 individuals from Kamouda 
Table 1. Caretta caretta. Sample sizes for nesting sites and foraging-habitat groups of Japanese loggerhead turtles. Sample sizes of mtDNA analysis for Minabe (MN), Miyzaki, Yakushima (YK), and Fukiagehama are from Hatase et al. (2002b). Females from Minabe were divided into 4 size groups by straight carapace length (mm) - MN-1: <800; MN-2: 800 to 850; MN-3: 850 to 900; MN-4: $\geq 900$. Females from Yakushima were divided into 2 groups based on stable isotope ratios in egg yolks - YK-Oc: oceanic forager; YK-Nr: neritic forager

\begin{tabular}{|c|c|c|c|c|c|c|c|c|c|c|c|}
\hline \multirow[t]{2}{*}{ Locus } & \multirow[b]{2}{*}{ Minabe } & \multirow[b]{2}{*}{ Kamouda } & \multicolumn{3}{|c|}{ - Nesting site } & \multirow[b]{2}{*}{ MN-1 } & \multicolumn{4}{|c|}{ Foraging-habitat group } & \multirow[b]{2}{*}{$\mathrm{YK}-\mathrm{Nr}$} \\
\hline & & & Miyazaki & Yakushima & Fukiagehama & & $\mathrm{MN}-2$ & $\mathrm{MN}-3$ & $\mathrm{MN}-4$ & YK-Oc & \\
\hline mtDNA & 102 & 20 & 46 & 89 & 22 & 20 & 45 & 23 & 11 & 8 & 40 \\
\hline $\mathrm{Cc} 7$ & 105 & 10 & 40 & 86 & 21 & 18 & 48 & 26 & 11 & 8 & 40 \\
\hline Cc117 & 111 & 8 & 42 & 83 & 19 & 19 & 48 & 28 & 12 & 8 & 40 \\
\hline Cc141 & 110 & 9 & 42 & 81 & 21 & 19 & 50 & 27 & 11 & 8 & 40 \\
\hline $\mathrm{Cm} 84$ & 109 & 9 & 44 & 73 & 18 & 19 & 50 & 26 & 11 & 7 & 37 \\
\hline Ei8 & 112 & 10 & 43 & 77 & 21 & 20 & 50 & 27 & 12 & 6 & 39 \\
\hline
\end{tabular}

using the primer sets AKACB1 (Hatase et al. 2002b) and TCR6 (Norman et al. 1994). Nineteen samples with Haplotype B exhibited exactly the same 309 to $650 \mathrm{bp}$ sequence and could not be divided into any more haplotypes. Although 1 female had a sequence corresponding to Haplotype C, only 2 sites were discovered as new polymorphic sites outside the region sequenced by Bowen et al. (1995) and Hatase et al. (2002b). Newly determined 309 to $650 \mathrm{bp}$ sequences of Haplotypes B and $C$ were deposited in the DNA Data Bank of Japan (DDBJ; Accession Numbers AB290590, AB290591, AB548628, AB548629, and AB548631 to AB548646).

Classification into foraging-habitat groups. Stable carbon and nitrogen isotope ratios $\left(\delta^{13} \mathrm{C}\right.$ and $\left.\delta^{15} \mathrm{~N}\right)$ in egg yolks from 48 females that nested at Yakushima were measured (Hatase et al. 2002d); the females with a $\delta^{13} \mathrm{C}$ of less than $-18 \%$ and a $\delta^{15} \mathrm{~N}$ of less than $12 \%$ were estimated to inhabit oceanic waters (the oceanic Pacific, seafloor depth $>200 \mathrm{~m}$ ), whereas the other females were estimated to inhabit neritic waters (such as the continental shelf in the East China Sea and coastal waters of Japan, seafloor depth $<200 \mathrm{~m}$ ). Based on these findings, 8 females (mean \pm SD straight carapace length: $826 \pm 45 \mathrm{~mm}$ ) were classified into an oceanic foraging group, while the other 40 females $(854 \pm 43 \mathrm{~mm})$ were classified into a neritic foraging group (Table 1).

At Minabe, because stable isotope data were not available, straight carapace lengths of nesting females were alternatively used for classification into foraginghabitat groups. A total of 112 females were classified into 4 groups $(<800 \mathrm{~mm}, \mathrm{n}=20 ; 800$ to $850 \mathrm{~mm}, \mathrm{n}=51$; 850 to $900 \mathrm{~mm}, \mathrm{n}=29$; $\geq 900 \mathrm{~mm}, \mathrm{n}=12$; Table 1 ), because there had been significant differences in both egg-yolk $\delta^{13} \mathrm{C}$ and $\delta^{15} \mathrm{~N}$ among these categories at both Minabe and Yakushima (Hatase et al. 2002d). In this classification, small and large size groups roughly corresponded to oceanic and neritic foraging groups, respectively, owing to high variations in both $\delta^{13} \mathrm{C}$ and $\delta^{15} \mathrm{~N}$ within each size class.
Data analysis. Genetic diversities at microsatellite loci were expressed as the number of alleles and observed/expected heterozygosities $\left(H_{\mathrm{O}} / H_{\mathrm{E}}\right)$; the heterozygosities were calculated in the program GENEPOP Ver. 3.4 (Raymond \& Rousset 1995). Departure from Hardy-Weinberg equilibrium at each locus within each population and the linkage disequilibrium between loci within each population were tested by a Markov chain method (10000 dememorizations, 100 batches, and 5000 or 10000 iterations) with the above program. The sequential Bonferroni method (Rice 1989) was applied to correct for multiple simultaneous comparisons in the above 2 tests. If deviations from Hardy-Weinberg equilibrium were found, the existence of null alleles and genotyping errors was assessed (1000 randomizations) using MICRO-CHECKER Ver. 2.2.3 (Van Oosterhout et al. 2004). Genetic diversities at the mtDNA level were expressed as the number of haplotypes and the haplotype $(h)$ and nucletotide diversities $(\pi)$. The $h$ and $\pi$ values were calculated using the method of Nei (1987), taking into account the genetic distances between haplotypes estimated by the Jukes-Cantor method (Jukes \& Cantor 1969), in the program ARLEQUIN Ver. 2.000 (Schneider et al. 2000). Population size for each nesting site, which was represented as the number of nests per season, was cited from literature to explore the relationship between it and genetic diversities.

Genetic differentiations between foraging-habitat groups were tested using genotypic frequencies, because some loci might exhibit deviations from HardyWeinberg equilibrium. Microsatellite genotypes were permutated among samples (10000 randomizations) using a genotypic goodness-of-fit test (Goudet et al. 1996) that was implemented in FSTAT Ver. 2.9.3.2 (Goudet et al. 2002). Differences in mtDNA haplotype frequencies were examined using an exact test (500 000 of steps in Markov chain and 1000 dememorization steps) that was implemented in ARLEQUIN Ver. 2.000 (Schneider et al. 2000). For both mtDNA and microsatellite loci, an unbiased estimator of Wright's 
$F_{\text {ST }}(\theta)$ (Weir \& Cockerham 1984) was calculated between foraging-habitat groups or among nesting sites using 10000 steps of permutation tests in ARLEQUIN Ver. 2.000 (Schneider et al. 2000). For microsatellite loci, an unbiased estimator of Slatkin's $R_{\mathrm{ST}}(\rho)$ (Slatkin 1995) was also calculated between foraging-habitat groups or among nesting sites using 1000 steps of permutation tests with $R_{\mathrm{ST}}$ Calc (Goodman 1997). When the numbers of alleles were compared among nesting sites, rarefaction analysis was done to investigate the effect of undersampling using the Rarefaction Calculator (www2.biology.ualberta.ca/jbrzusto/rarefact.php; accessed 15 September 2010).

\section{RESULTS}

\section{Genetic diversities at microsatellite loci and mtDNA}

For Caretta caretta, the number of alleles per locus ranged from 10 (locus Cc7) to 15 (loci Cc117 and Ei8), with an average of 13.4 (Table 2 ). $H_{\mathrm{O}}$ values ranged from 0.500 (Cc7 in Kamouda, the 800 to $850 \mathrm{~mm}$ size group of Minabe [MN-2], the oceanic group of Yakushima [YK-Oc], and Cc117 in YK-Oc) to 1.000 (Cc141 in the $\geq 900 \mathrm{~mm}$ size group of Minabe [MN-4]), whereas $H_{\mathrm{E}}$ values ranged from 0.511 (Ei8 in Kamouda) to 0.908 (Cc141 in Kamouda). Overall means of $H_{\mathrm{O}}$ and $H_{\mathrm{E}}$ were 0.718 and 0.738 , respectively. While $H_{\mathrm{O}}$ at Cc117 and Cm84 within Yakushima, the largest nesting population in Japan (Table 3), were 0.651 and 0.740, respectively, those within Kamouda were 0.750 and 0.889 , despite its extremely small population size
(Table 3). Of 55 population/ locus combinations, 53 were in Hardy-Weinberg equilibrium after adjusting the significance $(\alpha)$ level for the number of pairwise comparisons of populations and loci $(\mathrm{n}=55 ; \alpha=0.01$; Table 2). Although combinations of Cc7 and Cc141 within Yakushima exhibited heterozygote deficiency, the existence of null alleles and genotyping errors was not suggested. Linkage disequilibrium was not observed between any loci in any population after sequential Bonferroni correction ( $\mathrm{n}=102$, test results of 8 pairwise comparisons were lacking due to small sample sizes; $\alpha=0.01$ ). Therefore, all 5 loci in each population were used for the following analyses.

Three mtDNA haplotypes (A, B, and C) were observed among a total of 279 samples from 5 nesting sites (Table 3), where Haplotype B was the most common and accounted for $89 \%$ of the total. The $h$ and $\pi$ values varied among nesting sites, from 0.058 and 0.00083, respectively, at Minabe to 0.415 and 0.00598 at Miyazaki (Table 3 ). Overall $h$ and $\pi$ values were 0.193 and 0.00277 , respectively. Because there were no significant differences in mtDNA haplotype frequencies between sampling years within each nesting site (Hatase et al. 2002b), samples from different years were pooled at each nesting site.

\section{Genetic differences between foraging-habitat groups within nesting sites}

At Yakushima, among the observed alleles, 1 or 2 specific alleles were predominant at each microsatellite locus (Fig. S1 in the supplement at www.intres.com/articles/suppl/m424p273_supp.pdf). Genotypic

Table 2. Caretta caretta. Genetic diversities at 5 microsatellite loci among nesting sites and foraging-habitat groups for Japanese loggerhead turtles. Group abbreviations as defined in Table 1. $K$ : number of alleles; $H_{\mathrm{O}}$ : observed heterozygosity; $H_{\mathrm{E}}$ : expected heterozygosity

\begin{tabular}{|c|c|c|c|c|c|c|c|c|c|c|c|c|c|c|c|}
\hline Site or group & $K$ & $\begin{array}{c}-\mathrm{Cc} 7 \\
H_{\mathrm{O}}\end{array}$ & $H_{\mathrm{E}}$ & $K$ & $\begin{array}{c}\text { Cc117 } \\
H_{\mathrm{O}}\end{array}$ & $H_{\mathrm{E}}$ & $K$ & $\begin{array}{l}\text { Cc141 } \\
H_{\mathrm{O}}\end{array}$ & $H_{\mathrm{E}}$ & $K$ & $\begin{array}{l}\mathrm{Cm} 84 \\
H_{\mathrm{O}}\end{array}$ & $H_{\mathrm{E}}$ & $K$ & $\begin{array}{c}-\mathrm{Ei} 8 \\
H_{\mathrm{O}}\end{array}$ & $H_{\mathrm{E}}$ \\
\hline Minabe & 6 & 0.590 & 0.664 & 12 & 0.748 & 0.727 & 12 & 0.773 & 0.825 & 12 & 0.789 & 0.765 & 13 & 0.732 & 0.772 \\
\hline Kamouda & 4 & 0.500 & 0.642 & 6 & 0.750 & 0.617 & 8 & 0.778 & 0.908 & 7 & 0.889 & 0.817 & 5 & 0.600 & 0.511 \\
\hline Miyazaki & 6 & 0.625 & 0.623 & 10 & 0.786 & 0.794 & 9 & 0.857 & 0.778 & 9 & 0.727 & 0.753 & 11 & 0.674 & 0.628 \\
\hline Yakushima & 9 & $0.593^{\mathrm{a}}$ & 0.653 & 13 & 0.651 & 0.713 & 12 & $0.815^{\mathrm{a}}$ & 0.857 & 11 & 0.740 & 0.753 & 12 & 0.649 & 0.700 \\
\hline Fukiagehama & 5 & 0.667 & 0.678 & 8 & 0.526 & 0.761 & 10 & 0.762 & 0.807 & 10 & 0.889 & 0.813 & 7 & 0.714 & 0.679 \\
\hline MN-1 & 5 & 0.667 & 0.694 & 7 & 0.842 & 0.802 & 8 & 0.789 & 0.848 & 8 & 0.789 & 0.785 & 9 & 0.750 & 0.701 \\
\hline MN-2 & 6 & 0.500 & 0.666 & 10 & 0.694 & 0.725 & 10 & 0.720 & 0.815 & 10 & 0.760 & 0.761 & 13 & 0.740 & 0.813 \\
\hline $\mathrm{MN}-3$ & 6 & 0.731 & 0.689 & 7 & 0.821 & 0.721 & 11 & 0.778 & 0.847 & 11 & 0.808 & 0.770 & 8 & 0.704 & 0.734 \\
\hline $\mathrm{MN}-4$ & 5 & 0.636 & 0.662 & 7 & 0.833 & 0.736 & 8 & 1.000 & 0.853 & 5 & 0.818 & 0.736 & 7 & 0.667 & 0.768 \\
\hline YK-Oc & 4 & 0.500 & 0.575 & 7 & 0.500 & 0.692 & 8 & 0.875 & 0.842 & 5 & 0.571 & 0.758 & 5 & 0.667 & 0.667 \\
\hline YK-Nr & 7 & 0.600 & 0.616 & 9 & 0.700 & 0.674 & 11 & 0.800 & 0.869 & 11 & 0.748 & 0.793 & 11 & 0.667 & 0.724 \\
\hline Overall & 10 & & & 15 & & & 13 & & & 14 & & & 15 & & \\
\hline Mean & & 0.601 & 0.651 & & 0.714 & 0.724 & & 0.813 & 0.841 & & 0.775 & 0.773 & & 0.688 & 0.700 \\
\hline
\end{tabular}


Table 3. Caretta caretta. Distribution of mtDNA haplotypes, genetic diversities, and population sizes among 5 nesting sites for Japanese loggerhead turtles. All data, except for Kamouda, on mtDNA distributions and diversities are from Hatase et al. (2002b). The numbers of nests per season were recorded during sampling periods, i.e. in the 1990s for Minabe (Hatase et al. 2002a), Miyazaki (Kamezaki et al. 2003), Yakushima (Kamezaki et al. 2003), and Fukiagehama (Kagoshima University Sea Turtle Research Group 2002), and in the early 2000s for Kamouda (Watanabe 2006)

\begin{tabular}{|c|c|c|c|c|c|c|c|}
\hline \multirow{2}{*}{$\begin{array}{l}\text { Nesting } \\
\text { site }\end{array}$} & \multicolumn{3}{|c|}{ Haplotype } & \multirow[t]{2}{*}{ Total } & \multirow{2}{*}{$\begin{array}{l}\text { Haplotype } \\
\text { diversity }(h)\end{array}$} & \multirow{2}{*}{$\begin{array}{l}\text { Nucleotide } \\
\text { diversity }(\pi)\end{array}$} & \multirow{2}{*}{$\begin{array}{l}\text { Nests per } \\
\text { season }\end{array}$} \\
\hline & A & B & $\mathrm{C}$ & & & & \\
\hline Minabe & 0 & 99 & 3 & 102 & 0.058 & 0.00083 & $29-349$ \\
\hline Kamouda & 0 & 19 & 1 & 20 & 0.100 & 0.00144 & $13-23$ \\
\hline Miyazaki & 0 & 33 & 13 & 46 & 0.415 & 0.00598 & $200-900$ \\
\hline Yakushima & 1 & 77 & 11 & 89 & 0.239 & 0.00339 & $600-1600$ \\
\hline Fukiagehama & 0 & 21 & 1 & 22 & 0.091 & 0.00131 & $18-125$ \\
\hline Total & 1 & 249 & 29 & 279 & 0.193 & 0.00277 & \\
\hline
\end{tabular}

frequencies were not significantly different between the 2 foraging-habitat groups at each microsatellite locus (Cc7, p = 0.945; Cc117, p = 0.732; Cc141, p = 0.392; Cm84, $\mathrm{p}=0.920 ;$ Ei8, $\mathrm{p}=0.488 ;$ Fig. S1). $F_{\mathrm{ST}}$ and $R_{\mathrm{ST}}$ over loci between foraging-habitat groups were -0.013 and -0.022 , respectively. These $F_{\mathrm{ST}}$ and $R_{\mathrm{ST}}$ values were not significantly different from $0(\mathrm{p}=0.877$ and 0.847 , respectively). Two mtDNA haplotypes (B and $\mathrm{C}$ ) were observed in the analyzed samples (Fig. S1). Haplotype frequencies were also not significantly different between the 2 foraging-habitat groups $(\mathrm{p}=$ $1.000)$, and $F_{\mathrm{ST}}$ was not significantly different from 0 $\left(F_{\mathrm{ST}}=-0.081, \mathrm{p}=1.000\right)$.

At Minabe, the allelic distributions in microsatellite loci were almost the same as at Yakushima (Fig. S2 in the supplement at www.int-res.com/articles/suppl/ m424p273_supp.pdf). There were no significant differences in genotype frequencies among 4 size groups at each microsatellite locus $(\mathrm{Cc} 7, \mathrm{p}=0.953$; Cc117, $\mathrm{p}=$ $0.473 ;$ Cc141, $\mathrm{p}=0.685 ; \mathrm{Cm} 84, \mathrm{p}=0.486 ;$ Ei8, $\mathrm{p}=0.601$; Fig. S2). $F_{\mathrm{ST}}$ and $R_{\mathrm{ST}}$ over loci among the 4 size groups were -0.005 and -0.005 , respectively. These $F_{\mathrm{ST}}$ and $R_{\mathrm{ST}}$ values were not significantly different from $0(p=0.887$ and 0.514 , respectively). Two mtDNA haplotypes (B and C) were observed in the analyzed samples (Fig. S2). Haplotype frequencies were not significantly different among the 4 size groups $(\mathrm{p}=1.000)$, and $F_{\mathrm{ST}}$ among the groups was not significantly different from $0\left(F_{\mathrm{ST}}=-0.025, \mathrm{p}=\right.$ 0.874 ). Because there was no genetic differentiation between foraginghabitat groups at the 2 nesting sites, samples at each nesting site were pooled and used in the following interpopulation comparisons.

\section{Genetic differences among nesting sites}

Global $F_{\text {ST }}$ at mtDNA among 5 nesting sites was $0.094(\mathrm{p}<0.001)$. Pairwise $F_{\text {ST }}$ between 2 nesting sites ranged from -0.024 to 0.268 , with 5 of 10 combinations being significantly different from 0 ( $\mathrm{p}<0.05$ ) (Table 4).

At all microsatellite loci, distributions of allelic frequencies were almost the same among nesting sites (Fig. S3 in the supplement at www.int-res.com/ articles/suppl/m424p273_supp.pdf). Although some alleles were not observed in Kamouda and Fukiagehama, those missing alleles were probably due to smaller sample sizes rather than the existence of beach-specific alleles, because those alleles had low frequencies in Minabe, Miyazaki, and Yakushima. Rarefaction analysis confirmed this interpretation, because the numbers of alleles in subsamples from Minabe, Miyazaki, and Yakushima were quite similar to those in the samples from Kamouda and Fukiagehama at all loci (Table 5). Global $F_{\mathrm{ST}}$ among the 5 nesting sites did not exhibit significant departure from $0\left(F_{\mathrm{ST}}=0.003, \mathrm{p}=0.112\right)$. Pairwise $F_{\mathrm{ST}}$ between 2 nesting sites ranged from -0.013 to 0.011 , with only 2 of 10 combinations (Minabe-Fukiagehama and Yakushima-Fukiagehama) being significantly different from $0(\mathrm{p}<0.05)$ (Table 4$)$. Pairwise $R_{\mathrm{ST}}$ between 2 nesting sites ranged from -0.020 to 0.009 , with all 10 combinations not being significantly different from 0 ( $p>0.05$ ) (Table 4). The original data on allelic and haplotype frequencies presented in Figs. S1 to S3 are available as Table S1 in the supplement at www.intres.com/articles/suppl/m424p273_supp.pdf.

Table 4. Caretta caretta. Genetic partitions among 5 nesting sites for Japanese loggerhead turtles. Above the diagonal are $F_{\mathrm{ST}}$ based on mtDNA sequence comparisons from Hatase et al. (2002b), with additional data from Kamouda; below the diagonal are partitions based on 5 microsatellite loci (upper value: $F_{\mathrm{ST}}$; lower value: $\left.R_{\mathrm{ST}}\right)$. Significant values $(\mathrm{p}<0.05)$ based on permutation tests are indicated by asterisks

\begin{tabular}{|lccccc|}
\hline & Minabe & Kamouda & Miyazaki & Yakushima & Fukiagehama \\
\hline Minabe & & -0.024 & $0.268^{*}$ & $0.056^{*}$ & -0.024 \\
Kamouda & -0.007 & & $0.117^{*}$ & -0.001 & -0.050 \\
& -0.005 & & & & \\
Miyazaki & 0.003 & -0.009 & & $0.061^{*}$ & $0.128^{*}$ \\
& 0.004 & -0.019 & & & 0.005 \\
Yakushima & -0.006 & -0.013 & -0.000 & & \\
Fukiagehama & 0.000 & 0.006 & 0.000 & & \\
& $0.009^{*}$ & 0.001 & 0.003 & $0.011^{*}$ & \\
& 0.006 & -0.020 & -0.010 & 0.009 & \\
\hline
\end{tabular}


Table 5. Caretta caretta. Results of rarefaction analysis on number of alleles at 3 larger nesting sites (Minabe, Miyazaki, and Yakushima). $K$ : number of alleles; $K_{\text {Kamouda }}$ and $K_{\text {Fukiagehama: }}$ number of alleles (mean $\pm \mathrm{SD}$ ) in subsamples the size of which is the same as at Kamouda and Fukiagehama, respectively

\begin{tabular}{|c|c|c|c|c|}
\hline Locus & Nesting site & $K$ & $K_{\text {Kamouda }}$ & $K_{\text {Fukiagehama }}$ \\
\hline $\mathrm{Cc} 7$ & $\begin{array}{l}\text { Minabe } \\
\text { Kamouda } \\
\text { Miyazaki } \\
\text { Yakushima } \\
\text { Fukiagehama }\end{array}$ & $\begin{array}{l}6 \\
4 \\
6 \\
9 \\
5\end{array}$ & $\begin{array}{l}4.4 \pm 0.8 \\
4.4 \pm 0.8 \\
4.7 \pm 1.0\end{array}$ & $\begin{array}{l}5.2 \pm 0.7 \\
5.3 \pm 0.7 \\
6.0 \pm 1.1\end{array}$ \\
\hline Cc117 & $\begin{array}{l}\text { Minabe } \\
\text { Kamouda } \\
\text { Miyazaki } \\
\text { Yakushima } \\
\text { Fukiagehama }\end{array}$ & $\begin{array}{r}12 \\
6 \\
10 \\
13 \\
8\end{array}$ & $\begin{array}{l}5.8 \pm 1.1 \\
6.6 \pm 1.1 \\
6.1 \pm 1.3\end{array}$ & $\begin{array}{l}7.8 \pm 1.1 \\
8.9 \pm 0.8 \\
9.0 \pm 1.3\end{array}$ \\
\hline Cc141 & $\begin{array}{l}\text { Minabe } \\
\text { Kamouda } \\
\text { Miyazaki } \\
\text { Yakushima } \\
\text { Fukiagehama }\end{array}$ & $\begin{array}{r}12 \\
8 \\
9 \\
12 \\
10\end{array}$ & $\begin{array}{l}7.3 \pm 1.2 \\
6.9 \pm 1.0 \\
7.8 \pm 1.2\end{array}$ & $\begin{array}{r}9.4 \pm 1.0 \\
\\
8.7 \pm 0.5 \\
10.2 \pm 1.0\end{array}$ \\
\hline $\mathrm{Cm} 84$ & $\begin{array}{l}\text { Minabe } \\
\text { Kamouda } \\
\text { Miyazaki } \\
\text { Yakushima } \\
\text { Fukiagehama }\end{array}$ & $\begin{array}{r}12 \\
7 \\
9 \\
11 \\
10\end{array}$ & $\begin{array}{l}6.2 \pm 1.2 \\
6.1 \pm 1.0 \\
6.2 \pm 1.1\end{array}$ & $\begin{array}{l}8.0 \pm 1.2 \\
7.5 \pm 0.9 \\
7.7 \pm 1.1\end{array}$ \\
\hline Ei8 & $\begin{array}{l}\text { Minabe } \\
\text { Kamouda } \\
\text { Miyazaki } \\
\text { Yakushima } \\
\text { Fukiagehama }\end{array}$ & $\begin{array}{r}13 \\
5 \\
11 \\
12 \\
7\end{array}$ & $\begin{array}{l}7.2 \pm 1.3 \\
6.1 \pm 1.2 \\
7.0 \pm 1.3\end{array}$ & $\begin{array}{l}9.5 \pm 1.2 \\
8.4 \pm 1.1 \\
9.5 \pm 1.1\end{array}$ \\
\hline
\end{tabular}

\section{DISCUSSION}

The present study did not provide evidence of sympatric population subdivision in a large marine reptile that exhibits alternative foraging behaviors. This result may be reasonable when considering that sea turtles are solitary and aggregate only during the breeding season. In social marine mammals, such as killer whales Orcinus orca, sympatric foraging specialists (ecotypes) are genetically distinct (Hoelzel et al. 2007). Foraging skills are learned and transmitted among individuals within respective ecotype societies. In contrast, solitary sea turtles develop foraging skills by themselves. Therefore, the extent of sympatric genetic structure may be dependent on the degree of sociality among large marine animals. As observed in other terrestrial and marine animals (e.g. Okello et al. 2008, Portnoy et al. 2010), gene flow among nesting sites examined by genetic markers with different resolutions and modes of inheritance showed contrasting patterns: greater gene flow at microsatellite DNA than at mtDNA. Because we obtained similar results with other sea turtle population studies using a comparable number of microsatellie loci ( 5 in the present study vs.
4 in FitzSimmons et al. 1997b, 5 in Bowen et al. 2005, and 7 in Carreras et al. 2007), it is unlikely that the findings in the present study would change dramatically with the use of more markers. In fact, although fine-scale population structure was assessed for loggerhead turtles nesting at the Cape Verde Islands with 11 microsatellite loci, no significant differentiation was found among the islands (Monzón-Argüello et al. 2010). We discuss these results in light of the evolution of sea turtle behaviors and the conservation of Japanese loggerheads Caretta caretta.

\section{Genetic similarity between foraging-habitat groups within nesting sites}

The lack of significant differences in genotype and haplotype frequencies between foraging-habitat groups within nesting sites suggests that large neritic and small oceanic individuals nesting at the same beach belong to the same genetic population. Sizerelated differences in feeding-habitat use would not be a limiting factor for gene flow between foraginghabitat groups. This genetic homogeneity is probably attributed to gene flow at mating habitats. Male loggerheads are also thought to show size-related differences in their use of feeding habitats (Hatase et al. 2002c). Individuals of the 2 groups would share a common mating habitat spatio-temporally. Mating generally occurs near nesting beaches prior to the nesting season (Limpus 1993), and mate choice based on foraging habitats would not occur there. Eastern Australian green turtles did not select mates by body size (Limpus 1993), and the same may be true for Japanese loggerheads. The absence of differentiation in mtDNA haplotype frequencies between foraging-habitat groups was also reported in female loggerheads nesting in Florida, USA (Reich et al. 2010).

Individual variation in growth rates at oceanic developmental stages was hypothesized as a key factor for determining whether Japanese loggerhead turtles stay in oceanic waters or recruit to neritic waters (Hatase et al. 2004, 2006, 2010). This model was analogous to the model proposed for salmonids, in which growth rate determines whether they stay in a river or go down to the ocean/lake during immature periods (Thorpe 1986). Life-history polymorphisms within some salmonid populations appeared to result from phenotypic plasticity expressed by individuals with the same genotypes (Jones et al. 1997, Olsson et al. 2006). The lack of genetic differences between feeding-habitat groups revealed in our study similarly suggests that variation in feeding-habitat use by adult loggerheads results from phenotypic plasticity. The fact that incubation environment greatly affects loggerhead hatchling 
phenotypes, such as body sizes and activity levels (Carthy et al. 2003), might support this conclusion.

\section{Gene flow among nesting sites}

Global $F_{\mathrm{ST}}$ and pairwise $R_{\mathrm{ST}}$ at microsatellite loci did not show significant departure from 0 , and genetic differences were not detected in most pairwise $F_{\mathrm{ST}}$ comparisons. These results were in contrast to those of the mtDNA analysis, which found significant global $F_{\mathrm{ST}}$ and significant pairwise $F_{\mathrm{ST}}$ in half of all 10 combinations among 5 nesting sites. The level of gene flow at microsatellite loci may be greater than that for mtDNA among Japanese populations. Because $F_{\mathrm{ST}}$ values depend on heterozygosities within populations, contrasting $F_{\mathrm{ST}}$ values between DNA markers may also be attributed to differences in the heterozygosities of the markers (Hellberg 2009). In fact, intra-population $H_{\mathrm{E}}$ values at 5 microsatellite loci (0.511 to 0.908 ) were higher than intra-population $h$ values at the mtDNA level (0.058 to 0.415). Furthermore, differences in effective population size between nuclear DNA and mtDNA (i.e. 4-fold smaller at the mtDNA level) may be responsible for the contrasting $F_{\mathrm{ST}}$ values (Birky et al. 1983). Similar results were reported in loggerhead turtles inhabiting the western North Atlantic (Bowen et al. 2005) and the Mediterranean (Carreras et al. 2007), and male-mediated gene flow was considered as a reasonable explanation. FitzSimmons et al. (1997b) reported similar results for Australian green turtles and discussed the mechanisms of male-mediated gene flow. Male-biased dispersal was unlikely to be the cause, because male turtles had the same level of fidelity to courtship areas near natal beaches as did female turtles (Limpus 1993, FitzSimmons et al. 1997a). Mating outside the courtship areas was thought to be the cause of gene flow between nesting sites. However, mating in feeding habitats, usually shared by several nesting populations, would not occur, because the receptive period of breeding females may be $<2$ wk (Comuzzie \& Owens 1990). Thus, only migration corridors were hypothesized to be the places where interbreeding between females and males from different nesting sites occurs.

Such a situation may also apply to loggerhead turtles nesting in Japan. The East China Sea is a major feeding habitat for Japanese loggerheads (Kamezaki et al. 1997), and coastal areas around Yakushima Island may be an important migration pathway for individuals that nest on beaches facing the Pacific Ocean (Hatase et al. 2002d). Females from Minabe, Kamouda, and Miyazaki could mate with males from Yakushima, and males from these 3 locations could mate with females from Yakushima in the course of migration to courtship areas near natal beaches.

\section{Implications for conservation}

The heavy decline in nesting female loggerheads at Minabe in recent years was thought to result from a decline in oceanic small females possibly due to pelagic fisheries (Hatase et al. 2002a). Our results suggest that the decline in oceanic females could also affect neritic females, because they belong to the same genetic population. Efforts to remove the threats to oceanic females are also needed to conserve neritic females. Conversely, protecting neritic females from bycatch in coastal fisheries will also contribute to the subsistence of oceanic females.

The present study suggests that male-mediated gene flow is a general feature in sea turtles rather than specific for regional populations (FitzSimmons et al. 1997b, Bowen et al. 2005, Carreras et al. 2007). Natal homing of female turtles limits gene flow between nesting sites (Allard et al. 1994). Such limitation should be critical for Japanese loggerhead populations, because there were only 15 beaches where $>10$ clutches were laid annually in the 1990s (Kamezaki et al. 2003). In small populations of threatened species, inbreeding depression is considered to be the most immediate genetic threat (Frankham et al. 2002). Franklin (1980) suggested that effective population size should not be $<50$ in the short term. Loss of genetic diversity caused by genetic isolation of small populations was suspected for Japanese populations. In fact, only 3 mtDNA haplotypes were detected among 279 individuals, and overall $h$ and $\pi$ values for Japanese loggerheads (0.193 and 0.00277, respectively) were lower than those for their southeastern USA counterpart (0.320 and 0.01437), which had 5 haplotypes among 197 individuals (Encalada et al. 1998). While genetic diversities at the mtDNA level were low, genetic diversities in microsatellite loci for nesting females at Kamouda (a small nesting beach, where only ca. 20 clutches were laid annually) were similar to those at Yakushima, the largest nesting population in Japan (Table 3). This indicates that male-mediated gene flow plays an important role in preventing genetic fragmentation between nesting sites. Male-mediated gene flow might have evolved as a general feature in sea turtles to compensate for the risk of genetic fragmentation caused by natal homing. Varied mtDNA diversities among nesting sites with significant global $F_{\mathrm{ST}}$, in contrast to similar microsatellite diversities among nesting sites with non-significant global $F_{\mathrm{ST}}$, imply that the collapse of even a small nesting beach like Kamouda would affect overall genetic diversity of Japanese loggerhead turtles, and that extirpated beaches would not be easily recolonized from other nesting populations due to female philopatry. The decline of the Miyazaki population, the second largest loggerhead rookery in Japan 
(Table 3), would obviously cause a dramatic decrease in the overall genetic diversity of Japanese loggerheads, because it had the highest $h$ and $\pi$ values among the 5 nesting sites and significant pairwise $F_{\mathrm{ST}}$ at the mtDNA level was found between it and the 4 other nesting sites. The uniqueness of Miyazaki implies that this population might have been a source during the postglacial range expansion of this species near the Japanese Archipelago. Conservation efforts are still needed for individual nesting populations in order to maintain the overall genetic diversity of Japanese loggerheads.

Acknowledgements. We thank T. Kamata, M. Okamoto, R. Iguchi, J. Nii, and F. Sakai, for field assistance and logistical support at Kamouda beach. We also thank H. Tanaka, S. Minamikawa, F. Fukuhara, the volunteers of the Kyoto University Sea Turtle Research Team, members of Yakushima Sea Turtle Research Group, members of Miyazaki Wild Animal Research Group, K. Nozaki, K. Tanaka, and members of Kagoshima University Sea Turtle Research Group for help with the collection and supply of samples. The Sea Turtle Association of Japan supplied tags, tagging pliers, and calipers. M. J. Miller helped to improve the manuscript. Y. Minegishi provided technical advice on our DNA analyses. Three anonymous referees provided constructive comments. This work was partly supported by grants from the Research Fellowships of the Japan Society for the Promotion of Science (JSPS) for Young Scientists (K.K.W., H.H., K.S., and Y.M.), from the JSPS 21st Century COE Program (Biodiversity and Ecosystem Restoration) at The University of Tokyo to K.K.W. and H.H., and from the Nippon Foundation to H.H. All experiments described here complied with current Japanese laws.

\section{LITERATURE CITED}

Allard MW, Miyamoto MM, Bjorndal KA, Bolten AB, Bowen BW (1994) Support for natal homing in green turtles from mitochondrial DNA sequences. Copeia 1994:34-41

Asahida T, Kobayashi T, Saitoh K, Nakayama I (1996) Tissue preservation and total DNA extraction from fish stored at ambient temperature using buffers containing high concentration of urea. Fish Sci 62:727-730

Bass AL, Good DA, Bjorndal KA, Richardson JI, Hillis ZM, Horrocks JA, Bowen BW (1996) Testing models of female reproductive migratory behavior and population structure in the Caribbean hawksbill turtle, Eretmochelys imbricata, with mtDNA sequences. Mol Ecol 5:321-328

Bearhop S, Fiedler W, Furness RW, Votier SC and others (2005) Assortative mating as a mechanism for rapid evolution of a migratory divide. Science 310:502-504

Berthold P (1991) Genetic control of migratory behaviour in birds. Trends Ecol Evol 6:254-257

Birky CW Jr, Maruyama T, Fuerst P (1983) An approach to population and evolutionary genetic theory for genes in mitochondria and chloroplasts, and some results. Genetics 103:513-527

Bowen BW, Abreu-Grobois FA, Balazs GH, Kamezaki N, Limpus CJ, Ferl RJ (1995) Trans-Pacific migrations of the loggerhead turtle (Caretta caretta) demonstrated with mitochondrial DNA markers. Proc Natl Acad Sci USA 92: 3731-3734
Bowen BW, Bass AL, Soares L, Toonen RJ (2005) Conservation implications of complex population structure: lessons from the loggerhead turtle (Caretta caretta). Mol Ecol 14: 2389-2402

Boyle MC, FitzSimmons NN, Limpus CJ, Kelez S, VelezZuazo X, Waycott M (2009) Evidence for transoceanic migrations by loggerhead sea turtles in the southern Pacific Ocean. Proc Biol Sci 276:1993-1999

Braendle C, Friebe I, Caillaud MC, Stern DL (2005) Genetic variation for an aphid wing polyphenism is genetically linked to a naturally occurring wing polymorphism. Proc Biol Sci 272:657-664

Caparroz R, Miyaki CY, Baker AJ (2009) Contrasting phylogeographic patterns in mitochondrial DNA and microsatellites: evidence of female philopatry and male-biased gene flow among regional populations of the blue-andyellow macaw (Psittaciformes: Ara ararauna) in Brazil. Auk 126:359-370

Carreras C, Pascual M, Cardona L, Aguilar A and others (2007) The genetic structure of the loggerhead sea turtle (Caretta caretta) in the Mediterranean as revealed by nuclear and mitochondrial DNA and its conservation implications. Conserv Genet 8:761-775

Carthy RR, Foley AM, Matsuzawa Y (2003) Incubation environment of loggerhead turtle nests: effects on hatching success and hatchling characteristics. In: Bolten $\mathrm{AB}$, Witherington BE (eds) Loggerhead sea turtles. Smithsonian Books, Washington, DC, p 144-153

Caut S, Guirlet E, Angulo E, Das K, Girondot M (2008) Isotope analysis reveals foraging area dichotomy for Atlantic leatherback turtles PLoS ONE 3:e1845

> Chen SF, Jones G, Rossiter SJ (2008) Sex-biased gene flow and colonization in the Formosan lesser horseshoe bat: inference from nuclear and mitochondrial markers. J Zool (Lond) 274:207-215

Comuzzie DKC, Owens DW (1990) A quantitative analysis of courtship behavior in captive green sea turtles (Chelonia mydas). Herpetologica 46:195-202

Dodd CK Jr (1988) Synopsis of the biological data on the loggerhead sea turtle Caretta caretta (Linnaeus, 1758). Biol Rep US Fish Wildl Serv 88:1-110

Encalada SE, Bjorndal KA, Bolten AB, Zurita JC and others (1998) Population structure of loggerhead turtle (Caretta caretta) nesting colonies in the Atlantic and Mediterranean as inferred from mitochondrial DNA control region sequences. Mar Biol 130:567-575

FitzSimmons NN (1998) Single paternity of clutches and sperm storage in the promiscuous green turtle (Chelonia mydas). Mol Ecol 7:575-584

FitzSimmons NN, Moritz C, Moore SS (1995) Conservation and dynamics of microsatellite loci over 300 million years of marine turtle evolution. Mol Biol Evol 12:432-440

FitzSimmons NN, Limpus CJ, Norman JA, Goldizen AR, Miller JD, Mortitz C (1997a) Philopatry of male marine turtles inferred from mitochondrial DNA markers. Proc Natl Acad Sci USA 94:8912-8917

FitzSimmons NN, Moritz C, Limpus CJ, Pope L, Prince R (1997b) Geographical structure of mitochondrial and nuclear gene polymorphisms in Australian green turtle populations and male-biased gene flow. Genetics 14 : 1843-1854

FitzSimmons NN, Moritz C, Bowen BW (1999) Population identification. In: Eckert KL, Bjorndal KA, Abreu-Grobois FA, Donnelly M (eds) Research and management techniques for the conservation of sea turtles. Marine Turtle Specialist Group Publication No. 4, IUCN/SSC, Gland, p $72-79$ 
Frankham R, Ballou JD, Briscoe DA (2002) Introduction to conservation genetics. Cambridge University Press, Cambridge

Franklin IR (1980) Evolutionary change in small populations. In: Soulé ME, Wilcox BA (eds) Conservation biology: an evolutionary-ecological perspective. Sinauer Associates, Sunderland, MA, p 135-149

Goodman SJ (1997) $R_{\mathrm{ST}}$ Calc: a collection of computer programs for calculating estimates of genetic differentiation from microsatellite data and determining their significance. Mol Ecol 6:881-885

- Goudet J, Raymond M, Meeus T, Rousset F (1996) Testing differentiation in diploid populations. Genetics 144: 1933-1940

Goudet J, Perrin N, Waser P (2002) Tests for sex-biased dispersal using bi-parentally inherited genetic markers. Mol Ecol 11:1103-1114

Gross MR (1996) Alternative reproductive strategies and tactics: diversity within sexes. Trends Ecol Evol 11:92-98

Harrison RG (1980) Dispersal polymorphisms in insects. Annu Rev Ecol Syst 11:95-118

Hatase H, Goto K, Sato K, Bando T, Matsuzawa Y, Sakamoto W (2002a) Using annual body size fluctuations to explore potential causes for the decline in a nesting population of the loggerhead turtle Caretta caretta at Senri Beach, Japan. Mar Ecol Prog Ser 245:299-304

- Hatase H, Kinoshita M, Bando T, Kamezaki N and others (2002b) Population structure of loggerhead turtles, Caretta caretta, nesting in Japan: bottlenecks on the Pacific population. Mar Biol 141:299-305

Hatase H, Matsuzawa Y, Sakamoto W, Baba N, Miyawaki I (2002c) Pelagic habitat use of an adult Japanese male loggerhead turtle Caretta caretta examined by the Argos satellite system. Fish Sci 68:945-947

- Hatase H, Takai N, Matsuzawa Y, Sakamoto W and others (2002d) Size-related differences in feeding habitat use of adult female loggerhead turtles Caretta caretta around Japan determined by stable isotope analyses and satellite telemetry. Mar Ecol Prog Ser 233:273-281

Hatase H, Matsuzawa Y, Sato K, Bando T, Goto K (2004) Remigration and growth of loggerhead turtles (Caretta caretta) nesting on Senri Beach in Minabe, Japan: life-history polymorphism in a sea turtle population. Mar Biol 144: 807-811

Hatase H, Sato K, Yamaguchi M, Takahashi K, Tsukamoto K (2006) Individual variation in feeding habitat use by adult female green sea turtles (Chelonia mydas): Are they obligately neritic herbivores? Oecologia 149:52-64

Hatase H, Omuta K, Tsukamoto K (2007) Bottom or midwater: alternative foraging behaviours in adult female loggerhead sea turtles. J Zool (Lond) 273:46-55

> Hatase H, Omuta K, Tsukamoto K (2010) Oceanic residents, neritic migrants: a possible mechanism underlying foraging dichotomy in adult female loggerhead turtles (Caretta caretta). Mar Biol 157:1337-1342

Hawkes LA, Broderick AC, Coyne MS, Godfrey MH and others (2006) Phenotypically linked dichotomy in sea turtle foraging requires multiple conservation approaches. Curr Biol 16:990-995

Hefti-Gautschi B, Pfunder M, Jenni L, Keller V, Ellegren H (2009) Identification of conservation units in the European Mergus merganser based on nuclear and mitochondrial DNA markers. Conserv Genet 10:87-99

Hellberg ME (2009) Gene flow and isolation among populations of marine animals. Annu Rev Ecol Evol Syst 40: 291-310

> Hoelzel AR, Hey J, Dahlheim ME, Nicholson C, Burkanov V, Black N (2007) Evolution of population structure in a highly social top predator, the killer whale. Mol Biol Evol 24:1407-1415

Jones MW, Danzmann RG, Clay D (1997) Genetic relationships among populations of wild resident, and wild and hatchery anadromous brook charr. J Fish Biol 51:29-40

Jukes TH, Cantor CR (1969) Evolution of protein molecules. In: Munro HN (ed) Mammalian protein metabolism. Academic Press, New York, NY, p 21-132

Kagoshima University Sea Turtle Research Group (2002) Fukiagehama. In: Kamezaki N, Toji Y, Matsuzawa Y (eds) Current status of Japanese loggerhead turtle nesting and beach environment. Sea Turtle Association of Japan, Osaka, p 54-55 (in Japanese)

Kamezaki N, Miyawaki I, Suganuma H, Omuta K and others (1997) Post-nesting migration of Japanese loggerhead turtle, Caretta caretta. Wildl Conserv Jpn 3:29-39 (in Japanese with English abstract)

Kamezaki N, Matsuzawa Y, Abe O, Asakawa H and others (2003) Loggerhead turtles nesting in Japan. In: Bolten AB, Witherington BE (eds) Loggerhead sea turtles. Smithsonian Books, Washington, DC, p 210-217

Limpus CJ (1993) The green turtle, Chelonia mydas, in Queensland: breeding males in the southern Great Barrier Reef. Wildl Res 20:513-523

> Lukoschek V, Waycott M, Keogh JS (2008) Relative information content of polymorphic microsatellites and mitochondrial DNA for inferring dispersal and population genetic structure in the olive sea snake, Aipysurus laevis. Mol Ecol 17:3062-3077

Lundberg P (1988) The evolution of partial migration in birds. Trends Ecol Evol 3:172-175

- Maekawa K, Nakano S, Yamamoto S (1994) Spawning behaviour and size-assortative mating of Japanese charr in an artificial lake-inlet stream system. Environ Biol Fishes 39:109-117

> Mansfield KL, Saba VS, Keinath JA, Musick JA (2009) Satellite tracking reveals a dichotomy in migration strategies among juvenile loggerhead turtles in the northwest Atlantic. Mar Biol 156:2555-2570

McClellan CM, Read AJ (2007) Complexity and variation in loggerhead sea turtle life history. Biol Lett 3:592-594

McClellan CM, Braun-McNeill J, Avens L, Wallace BP, Read AJ (2010) Stable isotopes confirm a foraging dichotomy in juvenile loggerhead sea turtles. J Exp Mar Biol Ecol 387: $44-51$

- Monzón-Argüello C, Rico C, Naro-Maciel E, Varo-Cruz N, López P, Marco A, López-Jurado LF (2010) Population structure and conservation implications for the loggerhead sea turtle of the Cape Verde Islands. Conserv Genet 11: $1871-1884$

Moritz C (1994) Applications of mitochondrial DNA analysis in conservation: a critical review. Mol Ecol 3:401-411

Nei M (1987) Molecular evolutionary genetics. Columbia University Press, New York, NY

Norman JA, Moritz C, Limpus CJ (1994) Mitochondrial DNA control region polymorphisms: genetic markers for ecological studies of marine turtles. Mol Ecol 3:363-373

Okello JBA, Masembe C, Rasmussen HB, Wittemyer G and others (2008) Population genetic structure of savannah elephants in Kenya: conservation and management implications. J Hered 99:443-452

Ólafsdóttir GÁ, Ritchie MG, Snorrason SS (2006) Positive assortative mating between recently described sympatric morphs of Icelandic sticklebacks. Biol Lett 2:250-252

Olsson IC, Greenberg LA, Bergman E, Wysujack K (2006) Environmentally induced migration: the importance of food. Ecol Lett 9:645-651 
Portnoy DS, McDowell JR, Heist EJ, Musick JA, Graves JE (2010) World phylogeography and male-mediated gene flow in the sandbar shark, Carcharhinus plumbeus. Mol Ecol 19:1994-2010

Raymond M, Rousset F (1995) GENEPOP (Version 1.2): population genetics software for exact tests and ecumenicism. J Hered 86:248-249

Reich KJ, Bjorndal KA, Frick MG, Witherington BE, Johnson C, Bolten AB (2010) Polymodal foraging in adult female loggerheads (Caretta caretta). Mar Biol 157:113-121

Rice WR (1989) Analyzing tables of statistical tests. Evolution 43:223-225

Sato K, Bando T, Matsuzawa Y, Tanaka H, Sakamoto W, Minamikawa S, Goto K (1997) Decline of the loggerhead turtle, Caretta caretta, nesting on Senri Beach in Minabe, Wakayama, Japan. Chelonian Conserv Biol 2:600-603

Schneider S, Roessli D, Excoffier L (2000) ARLEQUIN Ver.2.000: a software for population genetics data analysis. Genetics and Biometry Laboratory, University of Geneva, Geneva

Seminoff JA, Zárate P, Coyne M, Foley DG, Parker D, Lyon BN, Dutton PH (2008) Post-nesting migrations of Galápagos green turtles Chelonia mydas in relation to oceanographic conditions: integrating satellite telemetry with remotely sensed ocean data. Endang Species Res 4:57-72

Slatkin M (1995) A measure of population subdivision based

Editorial responsibility: Inna Sokolova,

Charlotte, North Carolina, USA on microsatellite allele frequencies. Genetics 139:457-462

Thorpe JE (1986) Age at first maturity in Atlantic salmon, Salmo salar: freshwater period influences and conflicts with smolting. Publ Spec Can Sci Halieut Aquat 89:7-14

Tsukamoto K, Nakai I, Tesch WV (1998) Do all freshwater eels migrate? Nature 396:635-636

- Van Oosterhout C, Hutchinson WF, Wills DPM, Shipley P (2004) MICRO-CHECKER: software for identifying and correcting genotyping errors in microsatellite data. Mol Ecol Notes 4:535-538

Voss SR (1995) Genetic control of paedomorphosis in the axolotl, Ambystoma mexicanum: a test of the single-gene hypothesis. J Hered 86:441-447

Watanabe KK (2006) Studies on gene flow and migratory ecology in Japanese loggerhead turtles (Caretta caretta). PhD dissertation, The University of Tokyo, Tokyo (in Japanese)

> Weir BS, Cockerham CC (1984) Estimating F-statistics for the analysis of population structure. Evolution 38:1358-1370

> Wilbur HM, Collins JP (1973) Ecological aspects of amphibian metamorphosis. Science 182:1305-1314

- Zbinden JA, Bearhop S, Bradshaw P, Gill B, Margaritoulis D, Newton J, Godley BJ (2011) Migratory dichotomy and associated phenotypic variation in marine turtles revealed by satellite tracking and stable isotope analysis. Mar Ecol Prog Ser 421:291-302

Submitted: August 10, 2010; Accepted: December 10, 2010 Proofs received from author(s): February 18, 2011 